\title{
MODAL BUDAYA DAN MODAL SOSIAL: PENUNJANG BERKEMBANGNYA TOKO BANGUNAN YUNA JAYA
}

\author{
Ayu Musliha \\ Universitas Jember \\ Email : ayumusliha001@gmail.com
}

\begin{abstract}
In fact, the development of a business does not only talk about how economic capital is managed by business actors. Cultural capital and social capital are also important aspects in the process of developing a business. This research uses qualitative methods with data collection techniques through interviews and participatory observation. The informant investigates the business owner and one of the customers. The results of the study indicate that the capital owned by the business owner benefits the business actor for running his business. Meanwhile, social capital in the form of trust can enhance existing social networks and build new social networks. The maintenance process is carried out by business owners through loyalty to sales / bosses and buyers. So, it can be concluded that social capital and cultural capital also play an important role in the process of developing a business.
\end{abstract}

Keywords : Cultural capital, social capital, capital circulation

\begin{abstract}
Abstrak: Perkembangan suatu usaha nyatanya tidak hanya berbicara mengenai bagaimana suatu modal ekonomi dikelola oleh pelaku usaha. Modal budaya dan modal sosial juga menjadi salah satu aspek penting dalam proses pengembangan suatu usaha. Penelitian ini menggunakan metode kualitatif dengan teknik pengumulan data melalui wawancara dan observasi partisipatif. Informan penelitian ialah pemilik usaha dan salah satu pelanggan. Hasil dari penelitian menunjukkan bahwa modal budaya yang dimiliki pemilik usaha menjadi keuntungan pelaku usaha untuk bisa mengembangkan usahanya. Sedangkan modal sosial berupa kepercayaan dapat memperkuat jaringan sosial yang ada dan membangun jaringan sosial baru. Adapun proses dalam pemeliharaan jaringan sosial ialah dengan pemeliharaan kepercayaan yang dilakukan oleh sang pemilik usaha melalui loyalitasnya kepada sales/juragan dan pembeli. Jadi, dapat ditarik kesimpulan bahwa modal sosial dan modal budaya juga berperan penting dalam proses pengembangan suatu usaha.
\end{abstract}

Kata Kunci : Modal budaya, modal sosial, perputaran modal

\section{PENDAHULUAN}

Toko Bangunan Yuna Jaya adalah toko yang berbasis pada penjualan bahan bangunan. Toko yang awalnya hanya berupa kedai kecil yang hanya menjual gamping atau kapur, sekarang sudah berkembang pesat menjual beragam macam bahan bangunan. Keahlian yang dimiliki oleh pemilik toko beserta relasi yang didapatkan semasa pemilik menjadi tukang membuat toko ini meskipun kecil mudah dikenal oleh banyak orang. Usaha yang semakin berkembang nyatanya tidak terlepas dari dana yang dikelola bersama oleh pemilik toko beserta rekannya yang mana ialah istrinya sendiri, meskipun pengelolaan keuangan tidak dikelola secara sitematis. Terlepas dari hal tersebut, perkembangan suatu usaha juga tidak hanya dipengaruhi oleh modal ekonomi yaitu berupa pengadaan dana. Perkembangan usaha nyatanya juga dipengaruhi oleh modal sosial dan modal budaya yang dimiliki oleh pemilik. Modal budaya yang dimiliki 
oleh pemilik mendorong pemilik bisa mengetahui bagaimana suatu kualitas dari barang yang nantinya akan dijual kepada pembeli atau konsumen beserta seberapa banyak kebutuhan yang nantinya akan digunakan. Sedangkan modal sosial berupa kepercayaan, mendorong munculnya suatu relasi yang terus berkembang baik antara pemilik dengan distributor atau juragan dan antara pemilik dengan pembeli.

Modal sosial dan modal budaya ternyata juga mengambil bagian penting dalam perkembangan suatu usaha. Terlebih lagi modal sosial yang mendorong terciptanya perputaran modal yang didapatkan dari distributor atau juragan maupun modal yang didapatkan dari perputaran uang dari pelanggan. Adapun permasalahan yang akan dijawab melalui penelitian ini adalah bagaimana peran modal budaya dan modal sosial dalam memperkuat dan memperluas jaringan sosial yang telah ada sebelumnya? Bagaimana modal sosial berdampak secara siginifikan terhadap perputaran modal usaha? Modal budaya yang dimiliki oleh sang pemilik toko menjadi salah satu faktor penting bagaimana usaha ini bisa berkembang dan mengejar ketertinggalan dari toko-toko di sekitarnya.

Modal budaya dan modal sosial juga bisa (Purwanto, 2015) pembahasannya mengenai modal budaya dalam pengembangan aspek usaha industri keramik Kasongan lebih membahas bagaimana peran modal budaya bisa menciptakan dan memperluas area dan bagaimana modal budaya tersebut bisa menciptakan mobilitas sosial vertikal di kalangan pengusaha. (Kadek Sriwati, 2016) membahas mengenai bagaimanana pengaruh persediaan dan piutang terhadap tingkat likuiditas pada Toko Sentral Bangunan Elektronik Poso.
Fokusnya lebih kepada aspek modal ekonomi yang dikelola oleh pemilik, seperti bagaimana manajemen keuangan yang harus dikelola beserta dampat terhadap likuiditas. (Lestari, 2016) pembahasannya mengenai bagaimana pengaruh dari perputaran kas, perputaran piutang usaha, dan perputaran persediaan barang terhadap profit atau keuntungan yang nantinya akan didapatkan. (Widharta \& Sugiharto, 2013) pembahasannya mengenai seberapa besar pengaruh bauran pemasaran dalam meningkatkan penjualan suatu usaha. Bauran pemasaran yang ada juga membahas bagaimana suatu permainan harga dilakukan oleh pemilik usaha.

Berdasarkan

penelitian

terdahulu, peneliti tertarik untuk menggali informasi lebih mendalam mengenai proses perkembangan usaha yang masih berbasis toko. Dalam hal ini, peneliti berusaha untuk mencoba mengisi kekosongan dari penelitian terdahulu yang lebih banyak membahas mengenai modal ekonomi. Terlepas dari hal tersebut, terdapat pula beberapa penelitian yang membahas mengenai modal sosial dan budaya tapi lebih merujuk ke dimensi mobilitas sosial vertikal yang terjadi antar pengusahanya. Melalui tulisan ini peneliti mencoba untuk mengungkap kembali bagaimana modal sosial dan modal budaya ikut andil dalam perkembangan suatu usaha.

\section{METODE PENELITIAN}

Penelitian ini menggunakan metode kualitatif yang berbasis pada studi kasus. Metode studi kasus bertujuan untuk menelaah suatu objek penelitian secara mendalam yang terjadi dalam suatu kelompok, lembaga, maupun individu. Teknik pengumpulan data yang digunakan adalah teknik wawancara dan observasi partisipasi. Melalui teknik wawancara, peneliti bisa 
mendapatkan informasi yang lebih akurat mengenai permasalahan penelitian. Sedangkan dengan observasi partisipasi, peneliti yang ikut terjun langsung dalam kehidupan sehari-hari narasumber dapat menangkap berbagai informasi yang tidak bisa didapatkan melalui teknik wawancara. Lokasi penelitian berada di Desa Tanggul Wetan, Kecamatan Tanggul, Kabupaten Jember. Informan dalam penelitian ini berjumlah 3 orang, yaitu: 1. Sumarsono sebagai pendiri sekaligus pemilik usaha, 2. Wiwik Solihatin sebagai istri, pengelola keuangan, dan transaksi dengan beberapa pelanggan maupun distributor, 3. Lek To atau Warsito yang merupakan pelanggan.

\section{HASIL DAN PEMBAHASAN}

Toko bangunan adalah suatu toko yang menjual berbagai macam bahan-bahan untuk keperluan suatu pembangunan. Toko yang diberi nama Toko Bangunan Yuna Jaya ialah suatu toko yang masih berbasis toko biasa bukan CV maupun UD. Toko yang berdiri sekitar tahun 2011 bertempat di daerah Tanggul Wetan, Tanggul, jember. Pada daerah ini, banyak juga toko-toko bangunan yang berdiri dikarenakan daerah ini yang sudah masuk kategori semi perkotaan. Banyaknya pembangunan meskipun dalam lingkup kecil seperti, sekolah, rumah makan, dan cafe mendorong masyarakat untuk memanfaatkan kesempatan ini untuk mebuka toko. Toko Bangunan Yuna Jaya yang sudah berdiri sejak tahun 2011 pertama kali didirikan sebagai suatu alih profesi dari sang pemilik yang pada awalnya menjual makanan pada malam hari, yaitu Tahu Petis.

Pada awalnya, toko ini hanya menjual gamping atau kapur yang didapatnya dari tetangganya yang kebetulan seorang juragan kapur. Pada saat itu, hanya ada sekitar 2-3 tong besar yang dimilikinya, hingga sekarang sudah ada hampir 15 tong. Proses pengirimannya juga menggunakan becak atau para pembeli langsung datang ke toko dengan membawa karung jika hanya membeli dalam jumlah sedikit. Lambat laun toko ini mulai berkembang bahkan sudah mulai dikenal di daerah Tanggul dan sekitarnya dengan sebutan "Sumar Gamping". Panggilan "Sumar Gamping" merujuk pada nama pemilik yaitu Sumar dan gamping merujuk ke barang yang dijual oleh toko. Hingga saat ini, toko ini sudah memilki 2 unit transportasi untuk pengiriman barang yaitu berupa tosa dan 2 karyawan yang berasal dari kerabat terdekatnya.

Awal pendirian toko sebenarnya dilatarbelakangi oleh keinginan dari si pemilik untuk meningkatkan taraf hidupnya. Hal ini juga tidak terlepas dari dukungan keluarga saat awal-awal berjualan. Saat awal toko ini berdiri, pemilik bersama istrinya masih berjualan makanan pada malam harinya dan pagi sampai sore hari akan berada di toko. Namun akhirnya, pemilik memutuskan untuk berhenti berjualan makanan dan memutuskan untuk mengelola toko bangunan ini secara maksimal. Jaringan yang dimiliki oleh pemilik memudahkannya untuk mengisi kekosongan barang yang dulunya hanya berjualan kapur atau gamping saja, lambat laun berjualn batu bata, semen hingga besi. Proses pencarian seorang distributor ataupun juragan, pemilik juga turun langsung untuk melihat seberapa baik kualitas barang yang nantinya akan dijual. Hal ini dilakukan oleh pemilik agar barang yang dijual nantinya tidak akan mengecewakan pembelinya dan sesuai dengan tujuan sang pemilik yang menginginkan agar toko ini bisa long life.

Pengetahuan yang dimiliki oleh pemilik nampaknya diperoleh semasa mudanya saat menjadi seorang tukang 
bangunan baik di daerahnya sendiri maupun di luar daerah. Hal ini sesuai dengan tradisi yang berkembang di daerah sekitar yang mana jika salah satu keluarga merupakan seorang tukang bangunan dan ada anggota keluarga lain ada yang belum bekerja, nantinya anggota keluarga yang belum bekerja ini akan diajak. Tradisi seperti ini tidak hanya pada keluarga yang anggotanya tukang bangunan, tapi juga pada pekerjaan lain. Pengalaman tersebutlah yang membuat pemilik bisa tau bagaimana suatu kualitas dari suatu barang yang layak untuk digunakan pada suatu pembangunan. Pemilik bekerja ikut dengan pamannya tidak hanya dalam jangka waktu 1 atau 2 tahun, tapi bisa dikatakan mulai beliau remaja. Hal ini sebagai dampak dari pendidikan sang pemilik yang putus sekolah selepas beliau lulus di SD atau Sekolah Dasar. Jadi, selama masa remaja sampai masa bujangnya beliau bekerja mengikuti pamannya hingga ke kota-kota besar, seperti Jakarta dan Surabaya.

\section{Modal Budaya sebagai Keuntungan Pemilik Usaha}

Proses berdirinya suatu usaha ternyata tidak hanya membutuhkan modal ekonomi berupa uang saja. Modal budaya sebagai salah satu pendorong dari berdirinya suatu usaha juga memegang peranan penting dalam hal ini. Teori modal pertama kali diperkenalkan oleh Piere Bourdieu. Melalui teorinya ini, Bourdie mencoba membahas mengenai regularitas dari tindakan individu dengan menolak adanya pandangan tentang objektivisme, subjektivisme, dan tindakan rasional. Dalam menjelaskan mengenai teorinya ini, Bourdieu lebih mengaitkannya dengan konsep kekuasaan yaitu mengenai habitus \& ranah (arena). Habitus ini sesuai dengan hakikat manusia yang dibekali dengan persepsi, pemahaman, apresiasi, dan evaluasi terhadap dunia sosialnya. Sedangkan ranah (arena) ialah suatu jaringan relasi antar posisi objektif yang berada di dalamnya. arena bisa juga disebut sebagai arena pertempuran atau arena perjuangan individu. Modal adalah suatu konsentrasi kekuatan spesifik yang beroperasi di dalam ranah. Setiap modal menuntut individu agar bisa menyesuaikan diri dan beradaptasi menggunakan habitus yang ada di dalam dirinya guna dapat mempertahan hidupnya. Secara singkat, modal lahir sebagai suatu dasar yang digunakan untuk membentuk dan mempertahankan suatu tatanan sosial. Bourdieu membagi modal menjadi 4, yaitu modal ekonomi, modal budaya, modal sosial, dan modal simbolik.

Modal budaya adalah suatu modal yang bisa diproduksi melalui pendidikan formal maupun warisan keluarga. Modal budaya berkaitan dengan aspek logika, etika, dan estetika yang dimiliki oleh seorang individu. Modal budaya pada dasarnya berupa keyakinan akan nilai-nilai mengenai segala sesuatu yang dipandang benar dan senantiasa diikuti. Modal budaya milik Bourdieu dibagi menjadi 3 bentuk yaitu:

\section{Embodied State}

Modal yang melekat yang melekat pada diri seseorang yang didapatkan secara sadar atau diwariskan dan akan menjadi bagian dari diri seseorang tersebut. Contoh: pengetahuan, keahlian keterampilan teknis, dan lain-lain.

\section{Objectif State}

Modal yang berupa barang atau media, seperti resep, formula, lukisan, dan lain-lain yang merupakan hasil dari kebudayaan itu sendiri.

\section{Institutionalized State}


Modal dalam bentuk institusional yang memiliki wujud yang bisa menunjuk akademik seseorang, seperti ijazah dan sertifikat. Modal ini bisa dikonversi kedalam modal ekonomi, dengan pandangan bahwa semakin tinggi pendidikan seseorang, maka semakin tinggi pula pendapatannya.

Modal budaya berbentuk embodied yang berupa keahlian yang dimilik oleh seseorang baik didapatkan secara sadar maupun diwariskan menjadi salah satu modal budaya yang dimiliki oleh pemilik Toko Bangunan Yuna Jaya. Pengalaman pemilik yang dulunya pernah bekerja sebagai tukang bangunan semasa bujang memberikan keuntungan tersendiri saat awal-awal mendirikan usaha. Hal ini seperti yang dijelaskan oleh salah satu narasumber yaitu Ibu Wiwik pada saat wawancara:

...Kalau buat yang laine,
mungkin lebih banyak
menguntungkan ya, bapakmu
dulu pernah jadi tukang dan itu
lumayan lama pas dia jadi
bujang. Itu menguntungkan kita,
soalnya kadang bapakmu juga
berperan jadi arsiteknya di sini,
ya ngatur-ngatur ini butuh
berapa banyak bahannya, kalau
segini enaknya gimana,...

Melalui keterangan tersebut, keahlian yang dimiliki oleh pemilik toko membuatnya mudah untuk mengelola toko. Apalagi sekarang toko sudah mulai lengkap barang-barang yang dijual, tentunya hal ini menarik minat pembeli untuk berbelanja. Sehingga tidak jarang pembeli yang berkonsultasi dengan pemilik terkait berapa jumlah barang yang seharusnya digunakan dalam bangunannya. Relasi tukang yang dimiliki pemilik juga memudahkannya untuk memberikan saran-saran tukang bangunan mana yang harus digunakan oleh pembeli yang meminta pendapatanya.

Keahlian dari pemilik juga diturunkan kepada keluarga terdekatnya yang dulunya bekerja bersama dengan pemilik di toko yaitu disarankan untuk membukan toko sendiri. Berbekal beberapa pengetahuan yang diajarkan semasa bekerja bersama sang pemilik, sanak saudara terdekat sudah mulai bisa membuka toko sendiri bahkan hal itu juga digunakan oleh pemilik untuk bekerja sama apabila terdapat kehabisa stok barang dan pembeli membutuhkannya dalam waktu cepat. Pekerjaan pemilik yang dulunya sebagai tukang bangunan juga tidak melepas kemungkinan bahwa beberapa toko yang berdiri sebelum adanya toko ini bahkan sekarang sudah berganti nama menjadi $\mathrm{CV}$ atau UD mengenal pemilik secara akrab. Melalui hal itu pula jaringan relasi sosial yang dibentuk pemilik toko semakin kuat dan semakin meluas seiring dengan berkembangnya waktu.

\section{Modal Sosial sebagai Alat untuk Memperkuat Jaringan Sosial}

Putnam mengungkapkan bahwa modal sosial merupakan salah satu ciri khas kehidupan yang terdiri dari jaringan, norma, dan kepercayaan yang membuat para anggotanya bertindak secara efektif untuk mencapai tujuan bersama. Modal sosial lahir sebagai hasil dari interaksi yang terjadi dalam jangka waktu yang lama dan terus menerus atau berkelanjutan (Azhari, 2018). Interaksi sosial yang terjadi menciptakan adanya suatu ikatan emosional yang terjalin erat antara individu satu dan lainnya. Terciptanya ikatan emosional memberikan suatu aspek positif terhadap terbentuknya suatu relasi yang didasari oleh kepercayaan yang kuat sehingga memudahkan terjalinnya suatu kerja sama antara satu dan lainnya. Kepercayaan yang menjadi dasar 
terbentuknya relasi bagi beberapa pengusaha dianggap sebagai suatu hal yang penting daripada sekedar modal ekonomi yang didapatkan dari perseorangan maupun lembaga.

Penguatan jaringan sosial dalam berusaha merupakan salah satu langkah yang harus diambil oleh pengusaha untuk mempertahankan dan mengembangkan usahanya. Jaringan sosial merupakan salah satu karakteristik yang ada dalam modal sosial. Jaringan sosial terjadi akibat adanya suatu interaksi antara individu dan kelompok dalam suatun lingkungan sosial. Hubungan yang tercipta lewat jaringan ini bisa membantu individu untuk mendapatkan dan menyebarluaskan informasi yang bisa membantu mereka untuk memenuhi kepentingan antara satu dan lainnya.

Pemanfaatan jaringan sosial dalam dunia usaha bisa membantu pengusaha memperluas informasi mengenai usahanya sendiri dan mendapatkan informasi dari pihak lain. Seperti dalam wawancara dengan Bapak Sumar berikut:

...Bapak: "Hahaha guyon mbak. Tapi ya gitu mbak, nanti mereka ya pada bilang kalau ada temene mau bangun atau kerabat e gitu. Beli di sana loh, di Pak Sumar, bahane bagus sekalian bisa konsultasi barange juga. Ya gitu itu mbak, atau kalau tukang gitu, mesti kalau yang udah kenal akrab bakalan diarahin di sini gitu”

Ayu : "Terus kalau salesnya gitu gimana?"

Bapak: "Kalau salas itu, kayak sales yang baru itu ya dateng ke sini gara-gara saran dari mas Dadang. Sales cat itu mbak" Ayu : "Ohh iya tau aku"
Bapak : "Lahh itu juga hasil saran dari tokonya mas dadang kan...

Berdasarkan keterangan yang didapatkan melalui informan, pembeli maupun sales didapatkan melalui jaringan sosial yang telah dibentuknya. Informasi dari mulut ke mulut yang dilakukan oleh pembeli maupun sales memudahkan pemilik toko untuk mengembangkan jaringan sosial yang telah ada sebelumnya. Seperti salah satu sales yang didapatkan melalui kerabat terdekatanya yaitu Mas Dadang yang dulunya bekerja bersama di toko pemilik. Jaringan sosial yang dibentuk baik melalui pembeli maupun sales bermanfaat untuk pengembangan suatu usaha. Jika untuk sales, mereka bisa memasarkan barang yang ada di perusahaannya denga lebih luas lagi jangkauannya. Sedangkan untuk pemilik usaha, sales baru dengan brand baru lebih memperkaya komposisi barang yang dijual di toko.

Jaringan sosial memudahkan pemilik usaha untuk mendapatkan pasokan barang apalagi ada barang yang telah habis di toko. Jaringan sosial yang dibentuk antar sesama pemilik toko di suatu daerah memudahkan mereka untuk saling membantu ketika toko kehabisan stok barang. Seperti yang diungkapkan oleh Bapak Sumar berikut:

"Kalau ini kita bisa minta ke sales, tapi kalau butuhnya cepet hari ini juga gitu, ya kita minta ke temen-temen bapak, relasi bapak sesama toko bangunan kan juga banyak dan bapak ya selalu jaga relasi itu biar gak ada tumpang tindih antara harga satu sama lain. Semisal bapak jual harga miring banget, itu nantinya bakal matiin harga pasaran. Makanya bapak itu selalu jual dengan harga yang normal wes. Kalau saat kita gak 
punya barang, terus barang yang mau dibeli itu kayak barang yang gak terlalu besar, kayak cat gitu, kita kan gak stok banyak. Itu tak saranin ke tokonya suamie gurumu itu, Bu Titin. Jadi sebisa mungkin kita selalu jaga usaha orang dan usaha kita itu tetap jalan gitu mbak"

Berdasarkan keterangan dari informan, kehabisan stok atau kekurangan stok barang bisa ditutupi dengan membeli langsung ke toko-toko yang memang sudah menjadi relasinya. Pemilik toko juga menerapkan suatu sistem harga jual barang yang ditetapkan untuk tokonya sendiri yaitu dengan tidak mematikan harga pasaran yang ada. Hal ini dilakukan sebagai suatu langkah antisipasi terjadinya tumpang tindih harga yang ada di pasaran. Selain itu, prinsip ini juga dilakukan untuk menjaga suatu usaha milik orang lain dan usaha milik sendiri agar bisa tetap berkelanjutan atau long life.

Loyalitas pemilik usaha baik kepada pembeli maupun distributor dalam arti ialah sales merupakan suatu langkah yang bisa membuktikan bagaimana pelanggan akan merasa nyaman dan dihargai saat berkunjung ke toko. Loyalitas ini sesuai dengan budaya yang memang dimiliki oleh pemilik toko, yang mana pemilik toko merupakan orang keturanan Madura. Dalam masyarakat Madura ada suatu tradisi yang memang tidak tertulis tapi dipegah teguh oleh setiap masyarakat yaitu mengenai menjamu seorang tamu yang berkunjung ke rumahnya. Masyarakat Madura akan mengeluarkan seluruh makanan yang ada di dapurnya untuk menjamu tamunya dan mereka akan merasa senang jika makanan tersebut habis. Hal inilah yang diterapkan di Toko Bangunan Yuna Jaya, yang mana setiap pagi harinya akan tersedia satu teko plastik berukuran sedang yang berisi teh hangat. Teh tersebut diperuntukkan untuk mereka yang sedang berkunjung atau untuk mereka yang nantinya akan mengirimkan barang ke toko. Selain teh, istri pemilik juga menyediakan es lilin yang biasanya akan diberikan kepada kurir yang mengirim barang ke toko atau kepada pelanggan. Tidak hanya minuman, toko juga menyediakan camilan seperti kacang tanah rebus, singkos rebus, ubi rebus, pisang goreng, rokok, dan lain-lainnya.

Jaringan sosial yang terjalin antara individu dengan kelompok terbentuk karena adanya suatu kepercayaan antara individu dan kelompok untuk saling bekerja sama menunjang kepentingan usaha antara satu dan lainnya. Penguatan jaringan sosial selain dilandasi dengan sikap saling percaya antara satu dan lainnya, tentunya juga didukung oleh faktor loyalitas antara pihak-pihak terkait. Semakin kuat jaringan sosial yang ada bisa menunjukkan bahwa kepercayaan yang dibangun antara satu dan lainnya semakin kuat pula. Dalam hal ini, kepercayaan antara pihak individu dan kelompok menjadi salah satu faktor yang bisa menetukan jaringan sosial tersebut akan bertahan lama dan berkelanjutan bukan memudar seiring dengan semakin menipisnya kepercayaan yang terjalin diantara individu dan kelompok.

\section{Efektivitas Modal Sosial dan Modal Budaya dalam Pengembangan Suatu Usaha}

Pengembangan suatu usaha didukung oleh berbagai faktor, seperti kualitas SDM, pengelolaan keuangan, kemitraan, operasional atau produksi, dan lain-lain (Cahyanti \& Anjaningrum, 2018). Seperti yang telah dijelaskan sebelumnya, modal budaya dan modal sosial memiliki pengaruh yang cukup penting dalam pengembangan suatu 
usaha. Modal budaya berupa keahlian yang dimiliki oleh pemilik usaha merupakan suatu keuntungan bagi suatu usaha. Selain itu, pengalaman yang dimiliknya juga memudahkan para pembeli dalam hal pemberian saran mengenai berapa banyak bahan yang nantinya akan dibutuhkan dalam bangunannya. Dalam hal ini, SDM yang berkualitas bisa mendukung suatu proses pengembangan suatu usaha untuk bisa lebih merambah pasar yang lebih luas lagi.

Modal sosial berupa kepercayaan juga berperan penting melalui adanya hubungan timbal balik dengan basis saling menguntungkan antar pengusaha. Situasi saling menguntungkan antar pengusaha dapat digunakan sebagai alat yang bisa saling membantu untuk memenuhi kepentingan satu dan lainnya. Selain itu adanya nilai budaya yang berkembang yaitu tradisi balas budi lebih bisa mengefektifkan terjadinya kegiatan saling menguntungkan di antara pihak terkait. Seperti yang terjadi pada pemilik Toko Bangunan Yuna Jaya, saat mereka kehabisan stok di toko, mereka akan coba menghubungi toko lain yang ada di sekitarnya untuk memenuhi permintaan dari konsumen. Lalu saat toko lain kehabisan stok barang, mereka juga akan menghubungi Toko Bangunan Yuna Jaya untuk mengambil barang. Biasanya saat terjadi hal ini, kedua belah pihak ada yang mengambil barangnya secara langsung, tapi juga ada yang membayarnya dikemudian hari atau bisa disebut juga piutang. Namun terkadang jika toko A membutuhkan barang dan sebelumnya toko B sudah mengambil barang di toko A, dalam proses ini ada suatu kesepakatan. Yaitu dengan memotong harga barang tersebut sesuai dengan apa yang diambil di toko B, yang nantinya toko $A$ hanya perlu membayar sebagian sesuai dengan barang yang telah diambil oleh toko B.
Proses pengembangan usaha juga membahas bagaimana proses perputaran modal yang ada dalam suatu usaha. Toko Bangunan Yuna Jaya selalu menekankan kepada setiap pembelinya bahwa semua barang yang ada di toko ialah milik sales atau juragannya, mereka hanya membantu sales untuk memasakan barang yang tentunya dilandasi sikap saling percaya antara satu dan lainnya. Hal ini menyebabkan terjadinya suatu proses perputaran modal yang terjadi antara pembeli, toko, dan sales atau juragan. Pembeli biasanya akan membayar dalam bentu cash ataupun biasanya piutang dan terkadang juga ada pembeli yang sudah percaya kepada toko akan menitipkan sejumlah uang kepada toko, yang nantinya akan diakumulasikan menjadi barang untuk keperluan pembangunan rumahnya. Uang-uang tersebut bisa berupa cash, piutang, maupun uang titipan akan digunakan oleh pemilik toko untuk membayar sales yang akan datang setiap minggunya. Selain itu, biasanya jika ada uang berlebih akan digunakan untuk membeli barang secara langsung kepada juragan jika stok di toko sudah mulai menipis.

antara $\begin{array}{cc}\text { Kepercayaan yang } & \text { dibangun } \\ \text { pihak-pihak } & \text { tersebut }\end{array}$
memudahkan Toko Bangunan Yuna Jaya bisa berkembang mengikuti tokotoko lain yang berada di sekitarnya. Sikap saling mengerti antara pihak-pihak terkait juga perlu dikelola tentang bagaimana ikatan emosional itu bekerja antara pemilik dan pembeli maupun antara pemilik dan sales atau juragan. Dalam hal ini pengembangan usaha tidak selalu bicara mengenai bagaimana uang itu dikelola oleh pemilik usaha, tapi bagaimana ikatan emosional yang ada dikelola dengan baik oleh pihak-pihak terkait. Loyalitas dari pemilik usaha juga menunjukkan bagaimana mereka yang menjadi koleganya akan bersikap. Akar 
tradisi balas budi yang berkembang di daerah sekitar juga semakin mempermudah terjadinya suatu kesepakatan sosial tidak tertulis yang berkembang antar sesama pelaku usaha. Penguatan usaha sendiri juga perlu dilakukan agar usaha sendiri tidak mengalami kemunduran, namun nyatanya pengelolaan hubungan kekerabatan melalui pemeliharaan ikatan emosional yang baik juga menjadi kunci saat usaha sendiri memiliki suatu problematika yang membutuhkan bantuan dari pihak luar. Kepercayaan baik antar pihak-pihak internal suatu usaha maupun antara pihak-pihak eksternal juga menjadi kunci bagaimana suatu usaha bisa berkembang mengikuti usaha-usaha lain di sekitarnya.

\section{KESIMPULAN}

Modal budaya dan modal sosial menjadi salah satu penunjang dalam proses pengembangan suatu usaha. Kepercayaan yang merupakan salah satu karakteristik dari modal sosial merupakan hal yang paling dipegang teguh oleh pemilik usaha. Kepercayaan inilah yang menjadi kunci dari berkembangnya Toko Bangunan Yuna Jaya. Tekad dari pemilik usaha yang ingin membuat usahanya long life dibentuk melalui sikap saling percaya antara pemilik usaha dengan distributor/juragan dan antara pemilik usaha dengan pembeli. Loyalitas dari pemilik usaha juga menjadi salah satu alasan mengapa pembeli selalu berdatangan bahkan dari tempat yang jauh. Loyalitas dan kepercayaan inilah yang menjadi kunci berkembangnya suatu jaringan sosial baru sekaligus memperkuat jaringan sosial yang telah ada sebelumnya. Selain itu faktor dari modal budaya diakui oleh pemilik sebagai suatu keuntungan baik untuk suatu usaha apalagi yang bergerak pada bidang properti. Terlepas dari modal ekonomi, nyatanya kedua modal tersebut juga memegang andil dalam suatu usaha. Jadi, berdasarkan data-data dan analasis yang telah disajikan bisa ditarik kesimpulan bahwa modal budaya dan modal sosial merupakan suatu aspek penting dalam proses pengembangan suatu usaha.

\section{DAFTAR PUSTAKA}

Azhari, F. (2018). Peran modal sosial dalam pengembangan jaringan usaha kecil menengah. Jurnal Administrasi Bisnis, 59(1), 153162.

Cahyanti, M. M., \& Anjaningrum, W. D. (2018). Faktor-Faktor Yang Mempengaruhi Perkembangan Usaha Kecil Sektor Industri Pengolahan Di Kota Malang. Jurnal Ilmiah Bisnis Dan Ekonomi Asia, 11(2), 73-79. https://doi.org/10.32812/jibeka.v11 i2.50

Kadek Sriwati, N. (2016). Pengaruh Persediaan dan Piutang Terhadap Tingkat Likuiditas pada Toko Sentral Bangunan Elektronik Poso. Jurnal Ekomen, 16(1), 19-27.

Lestari, N. (2016). Pengaruh Perputaran Kas, Perputaran Piutang Usaha, Dan Perputaran Persediaan Terhadap Profitabilitas Pada Perusahaan Sub Sektor Makanan Dan Minuman Yang Terdaftar Di Bursa Efek Indonesia Tahun 20112015. Jurnal Manajemen Dan Akuntansi.

Purwanto, A. (2015). Modal Budaya dan Modal Sosial dalam Industri Seni Kerajinan Keramik. MASYARAKAT: Jurnal Sosiologi, $18(2)$.

https://doi.org/10.7454/mjs.v18i2.3 727

Widharta, W. P., \& Sugiharto, S. (2013). 134744-ID-penyusunan-strategidan-sistem-penjualan. Manajemen 
Humanis Vol. 13 No. 1

Pemasaran Petra, 2(1), 1-15.

dan-sistem-penjualan-dalam-

https://www.neliti.com/id/publicati

rangka-meningkatkan-penjualanons/134744/penyusunan-strategi-

tok 